\title{
IMPLEMENTASI GREEN ECONOMY TERHADAP PEMBANGUNAN BERKELANJUTAN DI KOTA KEDIRI
}

\author{
Dewi Wungkus Antasari \\ dewiwung@gmail.com \\ Prodi Akuntansi, Fakultas Ekonomi, Universitas Islam Kediri \\ Jalan Sersan Suharmaji Nomor 38 Kediri
}

\begin{abstract}
ABSTRAK
Peningkatan jumlah pabrik di Kediri berbanding lurus dengan peningkatan volume limbahnya. Sampah kini telah menjadi masalah lingkungan utama yang akan memicu masalah lingkungan lainnya. Masalah lingkungan terjadi karena sampah yang berlebihan dan dapat menyebabkan banyak polusi lingkungan dan kesehatan bagi masyarakat. Hal ini dapat menyebabkan hambatan untuk melaksanakan kegiatan ekonomi dan kegiatan lainnya. Dalam jangka panjang, pembangunan berkelanjutan di Kota Kediri tidak dapat dicapai karena hambatan lingkungan tersebut. Tujuan penelitian ini adalah untuk menjelaskan konsep baru untuk mengorganisir sampah dengan baik melalui program 3R (reduse, reuse, dan recycle) sebagai penerapan konsep ekonomi hijau untuk mewujudkan pembangunan yang berkelanjutan di Kota Kediri. Penelitian ini menggunakan metode kualitatif dengan pendekatan fenomenologi dan studi kasus. Hasil penelitian ini direkomendasikan kepada orang-orang Kediri, pemerintah, dan juga kepada penulis.
\end{abstract}

Kata Kunci: Ekonomi Hijau, Pembangunan Berkelanjutan, 3R.

\begin{abstract}
The increase in the number of factories in Kediri is directly proportional to the rise in the volume of waste. Garbage has now become a major environmental problem that will trigger other ecological issues. Environmental problems occur because of excessive trash and can cause a lot of environmental pollution and health to the community. These issues can create obstacles to carry out economic activities and other activities. In the long run, sustainable development in the City of Kediri cannot be achieved because of these environmental obstacles. The purpose of this research is to explain the new concept to organize waste accurately through the 3R program (reduce, reuse, and recycle) as the application of the idea of the green economy to realize sustainable development in the City of Kediri. This research uses a qualitative method with a phenomenological approach and case studies. The results of this study are recommended to the people of Kediri, the government, and also to the authors.
\end{abstract}

Keywords: Green Economy, Sustainable Development, 3R.

\section{PENDAHULUAN}

Kota Kediri merupakan kota yang kini sedang berkembang dalam hal industri. Dengan besarnya tingkat konsumsi masyarakatnya, menjadikan kota yang dijadikan sasaran investasi perusahaan-perusahaan franchise nasional maupun internasional dan menjadikan kota Kediri semakin metropolit. Diantaranya, perusahaan yang memberikan produk berupa makanan cepat saji dengan konsep western seperti Pizza Hut, PHD (Pizza Hut Delivery), Mc'Donals, KFC, Mokko Factory, Jco Donuts, dan lain sebagainya. Juga rumah makan yang berkonsep The Middle Eastern seperti Doner Kebab, Kayana Kebab, dan Kebab Babarafi. Sementara rumah makan yang membawa konsep oriental seperti Peco- Peco, 
Ohayo, dan Ichiban Sushi sudah menjadi konsumsi yang tidak sulit untuk didapatkan warga kota Kediri. Kemudahan untuk mendapatkannya kini semakin didukung dengan adanya perusahaan jasa yang melayani jasa beli-antar makanan yang dikehendaki dengan membayarkan sejumlah uang yang tergolong terjangkau untuk budget masyarakat kota Kediri, seperti go-food, grab-food, dan lain sebagainya.

Seiring dengan pertambahan tingkat dan pola konsumsi masyarakat Kota Kediri, bertambah pula volume sampah akibat perilaku konsumsi tersebut. Dampak nyata yang telah dirasakan adalah menggunungnya tumpukan sampah yang ada di TPA (Tempat Pembuangan Akhir). Fenomena tersebut sebagai salah satu tolak ukur bahwa TPA adalah satu-satunya alternatif utama dan terakhir dalam penanganan sampah bagi sebagian besar masyarakat di Kota Kediri. Namun pada kenyataannya pola himpun-angkut-buang tersebut justru menyebabkan masalah baru, di samping itu banyak jenis-jenis sampah yang membutuhkan waktu lama untuk bisa terurai. Lamanya waktu penguraian sampah tersebut tidak sebanding dengan cepatnya laju pertambahan sampah dan sempitnya lahan TPA Kota Kediri. Hal ini yang dapat menyebabkan munculnya beberapa masalah-masalah baru. Seperti overloadnya TPA, semakin menyempitnya lahan, pencemaran lingkungan bagi warga sekitar yang akan menghambat kegiatan ekonomi dan pembangunan ekonomi di Kota Kediri.

\section{METODE PENELITIAN}

Penelitian ini merupakan jenis penelitian deskriptif kualitatif dengan menggunakan fenomenology approach dan pendekatan studi kasus. Penelitian kualitatif ini berusaha memahami dan menafsirkan makna suatu peristiwa interaksi tingkah laku manusia dalam situasi tertentu menurut perspektif peneliti sendiri. Penelitian fenomenologi akan berdiskusi tentang suatu objek kajian dan terlibat secara langsung dalam prosesnya. Penelitian ini bertujuan untuk memberikan solusi dan referensi dalam melakukan penanganan sampah dengan baik tanpa menyebabkan pencemaran dan dampak buruk terhadap pembangunan ekonomi.

\section{HASIL DAN PEMBAHASAN}

Permasalahan utama saat ini dalam rangka pengimplementasian green economy agar tercipta pembangunan yang berkelajutan adalah sampah. Banyaknya volume sampah yang tidak diimbangi dengan solusi pengolahan sampah akan menimbulkan masalah baru di 
Kota Kediri. Berikut ini adalah jenis-jenis sampah dan lamanya waktu penguraian menurut Dinas Kebersihan dan Pertamanan Kota Kediri.

Tabel 1. Jenis Sampah dan Lamanya Waktu Penguraian

\begin{tabular}{cc}
\hline Jenis Sampah & Lama Waktu Terurai \\
\hline Kertas & 2,5 Bulan \\
Kardus & 5 Bulan \\
Kulit Jeruk & 6 Bulan \\
Spon Sabun & 25 Tahun \\
Sepatu Kulit & 40 Tahun \\
Kain Nilon & 40 Tahun \\
Plastik & 80 Tahun \\
Alumunium & 100 Tahun \\
Gabus/ Sterofoam & Tidak Bisa Hancur \\
\hline
\end{tabular}

Sumber: Dinas Kebersihan dan Pertamanan Kota Kediri Tahun 2012.

Menurut sebagian masyarakat alternatif lain untuk menangani sampah adalah dengan cara membakar sampah. Hal ini sama membahayakannya dengan menimbun sampah. Sebagaimana yang telah disebutkan dalam Undang- Undang Nomor 18 Tahun 2008 Pasal 29 tentang larangan mengimpor sampah, mencampur sampah yang menyebabkan pencemaran dan kerusakan lingkungan, membuang sampah tidak pada tempatnya, melakukan penanganan sampah dengan pembuangan terbuka di tempat pemrosesan terakhir, membakar sampah yang tidak sesuai dengan pesyaratan teknis pengolahan sampah, dan memasukkan sampah ke dalam wilayah NKRI. Hal ini dapat dibuktikan dari data prosentase perlakuan memilah dan tidak memilah sampah penduduk Pulau Jawa pada tahun 2014 berikut ini:

Tabel 2. Perlakuan Memilah dan Tidak Memilah Sampah Penduduk Pulau Jawa pada Tahun 2014

\begin{tabular}{lcccc}
\hline \multirow{2}{*}{ Provinsi } & \multicolumn{2}{c}{ Sampah Dipilah } & Sampah & \\
\cline { 2 - 3 } & $\begin{array}{c}\text { Dipilah dan } \\
\text { sebagian } \\
\text { dimanfaatkan }\end{array}$ & $\begin{array}{c}\text { Dipilah } \\
\text { kemudian } \\
\text { dibuang }\end{array}$ & $\begin{array}{c}\text { Tidak } \\
\text { Dipilah }\end{array}$ & Total \\
\hline DKI JAKARTA & 3,39 & 7,95 & 11,34 & 88,65 \\
JAWA BARAT & 11,28 & 11,36 & 22,64 & 77,36 \\
JAWA & 10,95 & 11,09 & 22,04 & 77,96 \\
TENGAH & 16,15 & 11,45 & 27,6 & 72,4 \\
DIY & 8,39 & 7,1 & 15,49 & 84,51 \\
JAWA TIMUR & 9,63 & 7,68 & 17,31 & 82,69 \\
BANTEN & 8,75 & 10,09 & 18,84 & 81,6 \\
INDONESIA & & & & \\
\hline
\end{tabular}

Data diatas menunjukkan bahwa kesadaran penduduk Pulau Jawa untuk memilah dan mengolah sampah masih sangat minim. Karena penduduk merupakan subyek dan obyek 
pembangunan berkelanjutan, maka yang langkah awal yang perlu dilakukan adalah melakukan sosialisasi pentingnya pemilahan dan pengolahan sampah. Penduduk harus secara langsung terlibat langsung dalam upaya ini. Salah satu diantaranya program yang melibatkan pemberdayaan masyarakat dalam konsep green economy ini adalah program 3R (Reduce, Reuse, dan Recycle). Green economy atau ekonomi hijau merupakan sebuah gagasan yang bertujuan untuk meningkatkan kesejahteraan sosial tanpa adanya resiko kerusakan lingkungan. Hal ini sejalan dengan fenomena yang terjadi di Kota Kediri yang masyarakatnya yang secara tidak langsung cenderung eksploitatif terhadap sumber daya alam dalam penanganan sampah. Implementasinya adalah melalui program $3 \mathrm{R}$ tersebut. Sebagaimana yang telah disebutkan dalam Peraturan Menteri Negara Lingkungan Hidup Republik Indonesia Pasal 1 "Kegiatan reduce, reuse, dan recycle atau batasi sampah, guna ulang sampah dan daur ulang sampah yang selanjutnya disebut Kegiatan 3R adalah segala aktivitas yang mampu mengurangi segala sesuatu yang dapat menimbulkan sampah, kegiatan penggunaan kembali sampah yang layak pakai untuk fungsi yang sama atau fungsi yang lain, dan kegiatan mengolah sampah untuk dijadikan produk baru".

Sesuai dengan jenis kegiatannya, implementasi yang telah dilaksanakan Pemerintah Kota Kediri adalah program Bank Sampah. Selain pemerintah kota, masyarakat kota Kediri ikut terlibat dalam program green economy ini. Tujuannya selain untuk mengurangi pertambahan sampah yang akan menyebabkan kerusakan lingkungan, tetapi juga untuk memperdayakan masyarakat di tiap-tiap kelurahan yang nantinya akan mendapatkan keuntungan melalui program ini. Program Bank Sampah akan mampu memotivasi warga untuk tidak serta merta melakukan pembuangan sampah di TPA tetapi menuntut mereka untuk memilah-milah jenis sampah dan mengumpulkan sampah yang akan serahkan pasa Bank Sampah terdekat. Program Bank Sampah tersebut juga memiliki nilai ekonomi dari proses daur ulang yang dilakukan oleh warga sendiri. Dalam upayanya mengurangi sedikit demi sedikit sampah dan memanfaatkannya tanpa harus membuangnya, pemerintah Kota Kediri menyediakan fasilitas-fasilitas seperti kendaraan pengangkut sampah dan komposter yang digunakan untuk mengolah sampah basah. Dengan ini implementasi green economy akan mampu mewujudkan pembangunan yang berkelanjutan (sustainable development) di Kota Kediri. Pembangunan berkelanjutan (sustainable development) adalah proses pembangunan (lahan, kota, bisnis, masyarakat, dsb) yang berprinsip "memenuhi kebutuhan sekarang tanpa mengorbankan pemenuhan kebutuhan generasi masa depan" (menurut Brundtland Report dari PBB, 1987). Dalam UU No. 32 tahun 2009 Pasal 1 Ayat 3, 
pembangunan berkelanjutan didefinisikan sebagai "upaya sadar dan terencana yang memadukan aspek lingkungan hidup, sosial, dan ekonomi ke dalam strategi pembangunan untuk menjamin keutuhan lingkungan hidup serta keselamatan, kemampuan, kesejahteraan, dan mutu hidup generasi masa kini dan generasi masa depan”. Definisi ini masih senafas dengan definisi umum tentang pembangunan berkelanjutan (sustainable development) sebagai pembangunan yang memenuhi kebutuhan generasi sekarang tanpa mengorbankan kemampuan generasi yang akan datang untuk memenuhi kebutuhannya sendiri.

Bentuk lain dari aplikasi selain program Bank Sampah untuk mendukung penerapan teori ekonomi hijau adalah mulai menggunakan peralatan reusbale (yang dapat digunakan kembali) dalam kegiatan sehari-hari. Hal tersebut sudah mulai disuarakan oleh masyarakat yang peduli tentang lingkungan untuk menggunakan reusable straw atau sedotan nonplastik yang tidak sekali pakai dan dapat digunakan kembali, hal ini bertujuan untuk mengurangi sampah plastik. Masyarakat didesak untuk mulai berhenti menggunakan sedotan yang terbuat dari plastik karena plastik adalah salah satu jenis limbah yang membutuhkan waktu 80 tahun untuk terurai. Tentu ini akan menimbulkan masalah lingkungan baru bagi negara Indonesia, terutama kota Kediri. Sedotan yang dapat digunakan kembali menggunakan bahan-bahan yang tidak berbahaya dan dapat digunakan berkali-kali, misalnya yang terbuat dari stainlesteel, bambu dan kaca. Selain sedotan plastik, peralatan makan sekali pakai lainnya seperti sendok, garpu, dan sumpit sekali pakai atau yang berbahan dasar plastik didesak untuk tidak dikonsumsi lagi. Untuk menggerakkan pola pikir baru seperti ini mungkin membutuhkan waktu yang tidak singkat, akan tetapi hal tersebut membantu mengurangi volume limbah di Kota Kediri. Serupa dengan orang-orang yang peduli lingkungan yang mulai mempromosikan terobosan baru untuk membantu mengurangi volume sampah, beberapa pusat perbelanjaan di Kediri mulai menerapkan kurang lebih sama. Misalnya, Matahari Department Store, Miniso, Alfamart, Indomart mulai menerapkan kantong plastik (kresek) berbayar kepada para pelanggannya. Tujuan dari hal ini adalah untuk mendorong pelanggan untuk menggunakan kantong belanja non-plastik dan reusable daripada harus berulang kali membeli kantong plastik untuk berbelanja. Tentunya hal ini dapat membantu penerapan prinsip ekonomi hijau yang bertujuan untuk mengurangi volume sampah di Kediri. 


\section{PERAN MASYARAKAT}

Masyarakat merupakan peran sentral dalam terciptanya pembangunan berkelanjutan. Sejatinya masyarakat merupakan suatu subjek dan objek dalam pembangunan berkelanjutan. Untuk mencapai kondisi yang ideal ditengah kualitas dan kuantitas daya dukung alam yang semakin rendah dan terbatas dibutuhkan kualitas dan kuantitas masyarakat yang baik pula.

\section{TEORI NEO-KLASIK}

Jika melihat dari teori sejarah pengembangan ekonomi, dalam Mahdzab Neoklasik, tokoh- tokohnya merasa telah mampu mengatasi kelangkaan alam dengan kemajuan tekonologi secara terus-menerus. Namun pada kenyataannya sistem ekonomi tidak akan mampu keluar dari ekosistem yang di dalamnya seluruh aktivitas manusia berlangsung. Menurut Teori Neoklasik, unsur sumberdaya alam dan lingkungan tidak mempengaruhi fungsi froduksi. Fungsi produksi dalam teori neoklasik mencakup tenaga kerja $(\mathrm{N})$, kapital (K), dan perubahan teknologi (A) dengan bentuk $\mathrm{F}(\mathrm{N}, \mathrm{K}, \mathrm{A})$. Terbitnya buku Limits to Growth dari Club of Romedi awal tahun 1970 telah menggeser perdebatan atas masa depan pertumbuhan ekonomi. Para penulis Limits to Growth menyatakan adanya batas biofisik bagi pertumbuhan yang akan membawa pertumbuhan ekonomi kepada titik akhir. "Sayangnya, perlakuan terhadap preferensi, teknologi produksi, dan ekonomi terlihat tidak konvensional dan tidak masuk akal bagi banyak ekonom" (Beckmann, 1975). Pasca terbitnya buku Limits to Growth tersebut munculah gerakan lingkungan. Ahli pertumbuhan mulai memasukkan sumberdaya alam dan polusi ke dalam model pertumbuhan ekonomi selama era 1970an. Sebagai contoh, Stiglitz (1974) mengusulkan fungsi produksi agregat dengan tenaga kerja, barang modal, dan sumberdaya alam sebagai barang substitusi dalam produksi. Fungsi produksi yang digunakan Stiglitz adalah $\mathrm{F}(\mathrm{N}, \mathrm{K}, \mathrm{R})$ dimana $\mathrm{R}$ adalah laju pemakaian sumberdaya alam. Namun upaya Stiglitz tersebut tidak menjadikan sumberdaya alam dan lingkungan dengan serta merta memasuki arus utama kajian pertumbuhan dan pembangunan ekonomi.

\section{IMPLEMENTASI}

Menurut Program Pengembangan Kota Hijau (P2KH), pembangunan berkelanjutan memiliki tiga pilar utama yang saling berkelanjutan, termasuk:

(1) Pertumbuhan ekonomi, yaitu mempertahankan pertumbuhan ekonomi yang stabil dengan merestrukturisasi sistem produktif untuk menghemat sumber daya dan energi. 
(2) Keberlanjutan Sosial, yang menjamin keadilan sosial dalam distribusi kekayaan dan layanan sosial.

(3) Keberlanjutan Lingkungan, yaitu dengan menjaga lingkungan hidup agar nyaman dan aman melalui emisi nol

Meningkatnya jumlah industri dan teknologi yang berkembang di Kota Kediri, jika tidak disertai dengan kesadaran akan kelestarian lingkungan akan memiliki dampak yang mengancam lingkungan dan pertumbuhan ekonominya. Terjadinya fenomena kelebihan beban TPA, yang mengakibatkan polusi udara dan lingkungan akan berdampak pada kesehatan masyarakat sekitar, dan kemudian pada periode selanjutnya akan mengganggu proses kegiatan dan pertumbuhan ekonomi. Untuk mencegah dampak negatif lainnya terjadi, langkah pertama adalah mengurangi volume limbah. Ini dilakukan oleh Pemerintah Kota Kediri melalui program Bank Sampah, yang secara bertahap menghilangkan pola penanganan sampah yang dibuang. Mekanisme program Bank Sampah adalah sebagai berikut:

(1) Warga memilah sampah di rumah mereka. Diantaranya adalah kertas, plastik, dan sampah basah.

(2) Pada hari yang ditentukan oleh Bank Sampah di setiap desa, warga menyimpan sampah. Kemudian Bank Sampah mencatat dalam buku tabungan orang-orang yang nantinya akan ditukar dengan uang tunai dan kebutuhan dasar.

(3) Kegiatan daur ulang dilakukan oleh manajemen Bank Sampah dan juga warga sekitar yang berkontribusi terhadap penyimpanan limbah. Di sini pemberdayaan masyarakat juga bisa dilakukan.

(4) Produk yang sudah jadi daur ulang akan dijual dan kemudian hasil penjualannya akan dikembalikan ke pengelola dan warga.

Bentuk implementasi lain terjadi di beberapa pusat perbelanjaan di Kediri. Diantaranya adalah Matahari Department Store, Miniso, dan lainnya. Mulai menerapkan kantung plastik (kresek) berbayar, dengan tujuan mengurangi minat pelanggan untuk mengonsumsi plastik yang waktu penguraiannya sangat lama.

Beberapa upaya pengurangan limbah mungkin membutuhkan waktu singkat untuk diterapkan dan dengan tujuan mengurangi volume sampah di Kediri. Namun sedikit demi sedikit sampah pasti akan berkurang. Polusi udara yang berdampak pada kesehatan warga sekitar juga akan berkurang yang pada akhirnya akan berdampak menghambat kegiatan ekonomi di Kediri. Jika implementasi ekonomi hijau tidak segera terapkan, itu akan 
berdampak lebih buruk. Dampak-dampak ini mungkin tidak terlihat secara signifikan di masa sekarang, tetapi akan mempengaruhi kegiatan ekonomi di masa depan. Inilah yang menyebabkan terjadinya ketimpangan antar generasi, kondisi di mana generasi kita dan generasi pendahulu kita telah mengeksploitasi alam sedemikian rupa sehingga mereka tidak menyediakan cadangan yang memadai untuk dinikmati oleh generasi berikutnya. Sebagai contoh, cadangan minyak bumi Indonesia diperkirakan hanya cukup untuk satu generasi mendatang, Raharja dan Manurung (2001: 337). Jika dikaitkan dengan masalah yang ada di Kediri, ketidakadilan antar generasi yang akan terjadi adalah penyempitan lahan yang tersedia. Ini karena banyak tanah digunakan untuk kegiatan industri, pusat perbelanjaan, perumahan dan sebagainya. Situasi ini memang merupakan salah satu indikator kota maju. Namun, harus diketahui dari perspektif lain bahwa kegiatan industri, pusat perbelanjaan dan perumahan hanya akan meningkatkan volume limbah dan pencemaran lingkungan jika tidak dapat ditangani dengan bijak. Dengan terjadinya pencemaran lingkungan akan mempengaruhi stabilitas ekonomi bahkan kelestarian kehidupan sosial akan terancam. Karena itu, masyarakat adalah peran utama dalam mewujudkan pembangunan berkelanjutan, salah satunya adalah melalui penerapan ekonomi hijau. Masyarakat sebenarnya adalah subjek dan objek penciptaan pembangunan berkelanjutan, populasi besar dengan pertumbuhan yang cepat jika tidak disertai dengan sumber daya manusia yang berkualitas yang akan memperlambat pencapaian kondisi ideal antara kuantitas dan kualitas populasi dan daya dukung lingkungan semakin terbatas.

\section{KESIMPULAN DAN SARAN}

Penelitian ini dilakukan untuk mengetahui pengaruh konsep, teori dan penerapan ekonomi hijau terhadap pembangunan berkelanjutan di Kediri secara khusus. Untuk mengetahui berbagai elemen dan aspek yang dapat mendukung pencapaian pembangunan berkelanjutan di Kediri. Dari serangkaian kegiatan penelitian, penulis dapat menarik kesimpulan dari rumusan masalah yang ditemukan penulis, termasuk yang berikut:

(1) Ekonomi hijau adalah gagasan yang bertujuan untuk meningkatkan kesejahteraan sosial tanpa risiko kerusakan lingkungan. Cara untuk menerapkan teori ekonomi hijau di Kediri adalah dengan program 3R (reduce, reuse, dan recycle).

(2) Program 3R yang telah dilaksanakan oleh Kediri adalah program Bank Sampah.

(3) Program Bank Sampah tidak hanya berguna dalam aspek lingkungan, tetapi juga memberikan manfaat dalam aspek ekonomi dan pemberdayaan masyarakat. 
(4) Penerapan teori ekonomi hijau lainnya adalah mulai mempromosikan peralatan yang dapat digunakan kembali seperti sedotan, sendok, garpu, sumpit, dll. Serta menerapkan kantong plastik berbayar untuk mengurangi konsumsi plastik masyarakat kota Kediri pada khususnya.

(5) Dengan berkurangnya volume limbah, masalah lingkungan akan berkurang secara bertahap. Selanjutnya, kegiatan ekonomi akan kembali ke stabilitas dan aspek kehidupan sosial dan lingkungan akan berkelanjutan.

(6) Pihak-pihak yang memainkan peran penting dalam keberhasilan pembangunan berkelanjutan meliputi: kemauan politik pemerintah, peran lembaga lingkungan pemerintah, peran organisasi non-pemerintah atau yang biasa disebut Lembaga Swadaya Masyarakat (LSM), peran sektor industri, peran media massa, dan partisipasi masyarakat.

\section{DAFTAR PUSTAKA}

Konsep Pembangunan Berkelanjutan, http://sim.ciptakarya.pu.go.id/p2kh/knowledge/detail/pembangunan-berkelanjutan, [Diakses pada 12 Desember 2019]

Menteri Lingkungan Hidup: Peraturan Menteri No. 18 of 2008 tentang Pengelolaan Sampah. http://www.menlh.go.id/DATA/UU18-2008.pdf, [Diakses pada 24 April 2013].

Moeloeng, Lexy. J., Metode Penelitian Kualitatif, Bandung: Rosda; 2017.

Pembangunan Berkelanjutan. Available from: http://merakyat.com/nasional/opininasional/1854-penduduk-berkualitas-merupakan-modal-dasar-pembangunanberkelanjutan, Diakses pada 4 September 2013.

Peraturan Menteri Negara Lingkungan Hidup No. 13 Tahun 2012 tentang Pedoman Pelaksanaan Reduse, Reuse, dan Recycle Melalui Bank Sampah. Jaringan Dokumentasi dan Informasi Hukum Menteri Lingkungan Hidup. (Online), (http://jdih.menlh.go.id/pdf/ind/IND-PUU-7-2012-

Permen\%20LH\%2018\%20th\%202012\%20Ortala.pdf), diakses 27 September 2013.

Raharja, Pratama \& Manurung, Mandala, Teori Ekonomi Mikro, Jakarta: Lembaga Penerbit Fakultas Ekonomi Universitas Indonesia; 2001.

Reksowijoyo, Fajar. Email sent to: Dewi Wungus Antasari: 26 September 2013.

Soedomo, Soedarsono., Ekonomi Hijau: Pendekatan Sosial, Kultural, dan Teknologi; 2013.

Yuda, Madde: Ekonomi Hijau (B1-01-SS-12). Available from: http://madewahyudisubrata.blogspot.com/2012/11/green-economy-b1-01-ss12.html, [Diakses pada 18 April 2013]. 